\title{
The Impact of Growth Patterns of Retinoblastoma (Endophytic, Exophytic, and Mixed Patterns)
}

\author{
Retinoblastomda Büyüme Paternlerinin Etkisi \\ (Endofitik, Ekzofitik ve Karışık Paternler)
}

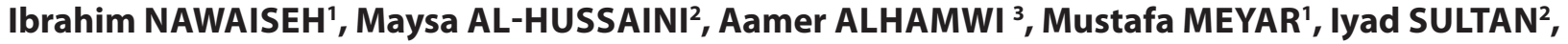 \\ Khalil ALRAWASHDEH ${ }^{1}$, Imad JARADAT ${ }^{4}$, Yacoub A YOUSEF ${ }^{1}$
}

Department of 'Surgery/Ophthalmology, ${ }^{2}$ Pathology, ${ }^{3}$ Pediatrics and ${ }^{4}$ Radiotherapy, King Hussein Cancer Center, AMMAN 11941, JORDAN

\begin{abstract}
Objective: To study the impact of the retinoblastoma growth pattern (endophytic vs. exophytic) on the clinical and pathological features after primary enucleation.

Material and Method: A retrospective case series of 42 eyes of 41 patients who had pathologically confirmed retinoblastoma. The main outcome measures included demographics, laterality, international intraocular retinoblastoma (IIRC) group, vitreous seeding, neovascular glaucoma, choroid invasion, optic nerve invasion,
\end{abstract} metastasis, and survival.

Results: The median age at diagnosis was 30 months. Nineteen (46\%) patients were males, and $17(41 \%)$ patients had bilateral retinoblastomas. Eight (19\%) eyes were IIRC group C, 20 (48\%) eyes were IIRC group D, and 14 (33\%) eyes were IIRC group E. Nineteen (45\%) tumors were endophytic, 14 (33\%) were exophytic, and $9(21 \%)$ were mixed. Choroid invasion was seen in $4(21 \%)$ of the endophytic tumors, 5 (36\%) of the exophytic tumors, and $8(89 \%)$ of the mixed tumors $(p=0.025)$. A mixed growth pattern was associated with massive choroid invasion in $5(56 \%)$ of eyes. Neovascular glaucoma was seen in $5(56 \%)$ of the mixed tumors $(\mathrm{p}=0.0376)$. Vitreous seeds were seen in $6(67 \%)$ of the mixed tumors $(\mathrm{p}=0.0448)$. Optic nerve invasion as well as patients' age at diagnosis, gender, and tumor laterality had no correlation with tumor growth pattern. At a median follow up of 36 months, no single case had metastasis or was dead.

Conclusion: Exophytic tumors have higher risk of choroid invasion, while endophytic tumors have higher risk of vitreous seeding. The mixed tumor growth pattern is associated with more advanced IIRC group, more risk of neovascular glaucoma, and more risk of massive choroid invasion.

Key Words: Choroid, Retinoblastoma, Eye, Prognosis

\section{ÖZ}

Amaç: Primer enükleasyon sonrası retinoblastomanın büyüme paternlerinin (endofitik, ekzofitik ve karışı) klinik ve patolojik özelliklere etkisini araştırmak.

Gereç ve Yöntem: Retinoblastoması patolojik olarak onaylanmış 41 hastaya ait 42 gözden oluşan retrospektif olgu serisi. Dahil edilen ana ölçümler: Demografik bilgiler, lateralite, uluslararası intraoküler retinoblastoma grubu (UİRG/IIRC) sinıfandırması, vitröz yayılım, neovasküler glokom, koroid invazyonu, optik sinir invazyonu, metastaz ve yaşam süresi.

Bulgular: Tanı anında medyan yaş 30 ay idi. Ondokuz (\%46) hasta erkekti ve 17 (\%41) hasta bilateral retinoblastomalıdi. Sekiz (\%19) göz IIRC grup C, 20 (\%48) göz IIRC grup D ve 14 göz IIRC grup $\mathrm{E}$ idi. Ondokuz (\%45) tümör endofitik, 14 (\%33) ekzofitik ve 9 (\%21) karışıktır. Koroid inazyonu endofitik tümörlerin 4 (\%21)'ünde, ekzofitik tümörlerin 5 (\%36)'inde ve karışık tümörlerin 8 (\%89)'inde görülmüştür $(\mathrm{p}=0,025)$. Karışı büyüme paterni gözlerin beşinde (\%56) massif koroid invazyonu ile ilişkilidir. Neovasküler glokom karıșık paternli tümörlerin 5 (\%56)'inde görülmüştür $(\mathrm{p}=0,0376)$. Vitröz yayılım karışık tümörlerin 6 (\%67)'sında görülmüștür ( $\mathrm{p}=0,0448)$. Optik sinir invazyonu yanı sıra tanı anında yaş, cinsiyet ve tümör lateralitesi tümör büyüme paterni ile ilişkili değildir. Medyan 36 aylık takipte hiç bir olguda ölüm veya metastaz görülmemiştir.

Sonuç: Ekzofitik tümörlerin daha fazla koroid invazyon riski, endofitik tümörlerin ise daha fazla vitröz yayılım riski vardır. Karıșık büyüme paterni daha ileri IIRC grubu, daha fazla neovasküler glokom ve massif koroid invazyonu ile ilişkilidir.

Anahtar Sözcükler: Koroid, Retinoblastoma, Göz, Prognoz
(Turk Patoloji Derg 2015, 31:45-50)

Received : 01.05.2014 Accepted : 18.05.2014
Correspondence: Yacoub A YOUSEF

King Hussein Cancer Center, Queen Rania Street,

P.O. Box 1269, Al-Jubaiha, AMMAN, JORDAN

E-mail: yyousef@khcc.jo Phone: +0096 2787228749 


\section{INTRODUCTION}

Retinoblastoma, a rare tumor arising from the retina, is the most common primary intraocular malignancy in childhood and infancy. The incidence is estimated at about 1 in 15,000 to 20,000 live births (1-3).

Retinoblastoma originates from the inner nuclear layer of the retina (4), and the clinical presentation is variable according to the growth pattern of the tumor. The growth pattern of retinoblastoma was divided into endophytic and exophytic types more than 100 years ago (5). Tumors that grow towards the vitreous cavity are called endophytic tumors, and they are visible clinically by ophthalmoscopy. Endophytic tumors are usually observed as a white retinal mass lesion surrounded by fine feeding vessels and sometimes tumor seeds. On the other hand, tumors that grow outwards between the sensory retina and retinal pigment epithelium are called exophytic tumors, and usually present as retinal detachment secondary to tumor that is invisible by ophthalmoscopy. Exophytic tumors initially appear as small grey masses that are difficult to identify. As a tumor grows, retinal detachment will be progressive and may end up with total retinal detachment (4). Some retinoblastomas manifest endophytic and exophytic growth patterns at the same time (mixed endophytic-exophytic retinoblastoma). Only $1-2 \%$ of cases of retinoblastoma exhibit a diffuse infiltrating growth pattern where the tumor grows diffusely within the retina without the formation of a discrete mass (6).

Diffuse infiltrating retinoblastomas are often misdiagnosed as uveitis since they present with signs suggestive of inflammation (7). Endophytic retinoblastoma may be misdiagnosed as astrocytic hamartoma, while exophytic retinoblastoma when present with total retinal detachment may be misdiagnosed as Coat's disease, persistent hyperplastic primary vitreous, retinopathy of prematurity, and retinal dysplasia $(8,9)$.

Herein we studied the association between tumor growth patterns (endophytic vs. exophytic) and the presence of high-risk pathological features (HRF) after enucleation.

\section{MATERIALS and METHODS}

This study was approved by the Institutional Review Board. It was a retrospective case series of 42 eyes of 41 consecutive patients from January 2006 to December 2012 that had a clinical diagnosis of intraocular retinoblastoma, which was confirmed pathologically after enucleation. Selection required access to patients' medical and pathological records.

Data included patient's age, gender, laterality, age at diagnosis, initial international intraocular retinoblastoma classification (IIRC) (10) group, presence of vitreous seeds, choroid invasion (focal versus massive), optic nerve invasion, metastasis, second malignancy and mortality.

Inclusion and exclusion criteria; The eligibility criteria for inclusion were eyes with a pathological diagnosis of intraocular retinoblastoma treated initially by enucleation without receiving any focal therapy, chemotherapy, or radiation therapy. Exclusion criteria included eyes that received any modality of treatment (focal therapy, chemotherapy, radiation therapy) before enucleation. All eyes with extra ocular retinoblastoma were excluded.

Pathological Characteristics and definitions: An endophytic tumor was defined as tumor that grows towards the vitreous cavity, and an exophytic tumor was defined as a tumor that grows outwards between the sensory retina and retinal pigment epithelium. When both patterns existed together, the growth pattern was considered as mixed.

Choroid invasion was defined as the presence of one or more solid nests of tumor cells that fill or replace the choroid and have pushing/infiltrative borders. Tumors were divided into three groups; 1 . No choroid invasion, 2. Focal choroid invasion (less than $3 \mathrm{~mm}$ in maximum diameter, width or thickness and not touching the sclera), and 3. Massive choroid invasion (solid tumor nest $3 \mathrm{~mm}$ or more in maximum diameter, width or thickness and touches the inner surface of the sclera).

Extent of optic nerve invasion was divided into three groups; 1. No optic nerve invasion, 2. Laminar or prelaminar optic nerve invasion and 3. Retrolaminar optic nerve invasion.

Statistical Analysis; Statistical analysis of tumor growth patterns were correlated to the gender, laterality, IIRC group, presence of vitreous seeds, presence of neo-vascular glaucoma, choroid invasion, and optic nerve invasion. The $P$ value was measured using the exact Fisher test to test the predictive power of each factor.

\section{RESULTS}

Between January 2006 and December 2012, there were 42 eyes of 41 patients with intraocular retinoblastoma (IIRC group $\mathrm{C}, \mathrm{D}$, or $\mathrm{E}$ ) treated by primary enucleation.

Demographics; The mean age at time of enucleation was 30 months (median, 29 months; range, 5-61 months). There were 19 males (46\%) and 22 females (54\%). There were 24 (59\%) unilateral and 17 (41\%) bilateral cases. The median follow up was 36 months (range; 12-90 months). The impact of patients' demographics on tumor growth pattern is presented in Table I. 
Tumor features: Of the 42 eyes in this series, 8 (19\%) eyes were IIRC group C, 20 (48\%) eyes were IIRC group $\mathrm{D}$, and 14 (33\%) eyes were IIRC group E. An endophytic growth pattern was seen in 19 (45\%) eyes, an exophytic growth pattern was seen in $14(33 \%)$ eyes, and an mixed growth pattern was seen in $9(21 \%)$ eyes (Figure 1A-E). An infiltrative growth pattern was not reported in any eye. Seven (88\%) of IIRC group C eyes were endophytic, 1 (13\%) was exophytic, and none was of the mixed type. Seven (35\%) of IIRC group D eyes were endophytic, 10 (50\%) were exophytic, and 3 (15\%) were of the mixed type. Five (36\%) of IIRC group E eyes were endophytic, 3 (21\%) were exophytic, and $6(43 \%)$ were of the mixed type (Table I). The mixed growth pattern was significantly associated with more advanced IIRC group ( $\mathrm{p}=0.0407)$.

The impact of growth pattern on pathological features; Choroid invasion was seen in $17(40 \%)$ eyes; 4 (21\%) of endophytic tumors, 5 (36\%) of exophytic tumors, and 8 $(89 \%)$ of mixed tumors. An exophytic component was significantly associated with higher risk of choroidal invasion ( $\mathrm{p}=0.0252)$. Focal choroidal invasion was seen in $11(26 \%)$ eyes, and massive choroidal invasion was seen in 6 (14\%) eyes. There was no single case of endophytic tumor associated with massive choroidal invasion, while a mixed growth pattern was associated with massive choroidal invasion in $5(56 \%)$ eyes with statistical significance $(\mathrm{p}=0.0498)$ (Table II).

Optic nerve invasion was seen in 17 (40\%) eyes; 8 (42\%) of the endophytic tumors, 4 (29\%) of the exophytic tumors, and $5(56 \%)$ of the mixed tumors, with no statistical significance ( $\mathrm{p}=0.321)$. Of note, $2(11 \%)$ of the endophytic tumors, and $3(33 \%)$ of the mixed tumors had post-laminar optic nerve invasion while no single exophytic tumor had post-laminar optic nerve invasion (Table II).

A clinical diagnosis of neovascular glaucoma was made in $3(16 \%)$ of the endophytic tumors, $3(21 \%)$ of the exophytic tumors, and 5 (56\%) of the mixed tumors. Tumors with a mixed growth pattern were at higher risk to develop neovascular glaucoma than non-mixed tumors $(\mathrm{p}=0.0376)$. Vitreous seeds were seen in $14(74 \%)$ of the endophytic tumors, 5 (36\%) of the exophytic tumors, and 6 $(67 \%)$ of the mixed tumors. Vitreous seeds were seen more commonly with endophytic tumors or tumors with an endophytic growth component than with exophytic tumors $(p=0.0448)$. Patients' gender, age, and tumor laterality were not associated with significant difference in the growth pattern of the tumor (Table II). All patients with high-risk pathological features received adjuvant chemotherapy. No single case had metastasis or was dead at the last date of follow up.

\section{DISCUSSION}

Some histopathological findings in enucleated eyes with retinoblastoma, designated as high-risk pathologic features, are associated with a higher risk of tumor metastasis, and therefore need additional treatment such as adjuvant chemotherapy. These high-risk features include massive choroid invasion, post-laminar invasion of the optic nerve, invasion of the optic resection margin, and tumor invasion of the anterior chamber, iris, cilliary body, sclera, as well as extra-ocular tumor extension (11-16).

Endophytic tumors grow towards the vitreous cavity and present as a vascular intraocular mass, while exophytic tumors grow between the retina and the retinal pigment

Table I: Patients' demographics and tumor growth pattern

\begin{tabular}{|l|c|c|c|c|c|c|c|c|}
\hline Growth Pattern & No. & \% & Endophytic & \% & Exophytic & \% & Mixed & \% \\
\hline Patients & 41 & & & & & & & \\
\hline Male & 19 & 46 & 11 & 58 & 5 & 26 & 3 & 16 \\
\hline Female & 22 & 54 & 8 & 36 & 9 & 41 & 5 & 23 \\
\hline Eyes & 42 & & 19 & 45 & 14 & 33 & 9 & 22 \\
\hline Unilateral & 24 & 59 & 11 & 46 & 10 & 42 & 3 & 12 \\
\hline Bilateral & 17 & 41 & 8 & 47 & 4 & 24 & 5 & 29 \\
\hline Right & 25 & 60 & 10 & 40 & 10 & 40 & 5 & 20 \\
\hline Left & 17 & 40 & 9 & 53 & 4 & 23.5 & 4 & 23.5 \\
\hline IIRC ${ }^{\star}$ C & 8 & 19 & 7 & 88 & 1 & 12 & 0 & 0 \\
\hline IIRC D & 20 & 48 & 7 & 35 & 10 & 50 & 3 & 15 \\
\hline IIRC E & 14 & 33 & 5 & 36 & 3 & 21 & 6 & 43 \\
\hline
\end{tabular}

*IIRC: International Intraocular Retinoblastoma Classification (10). 

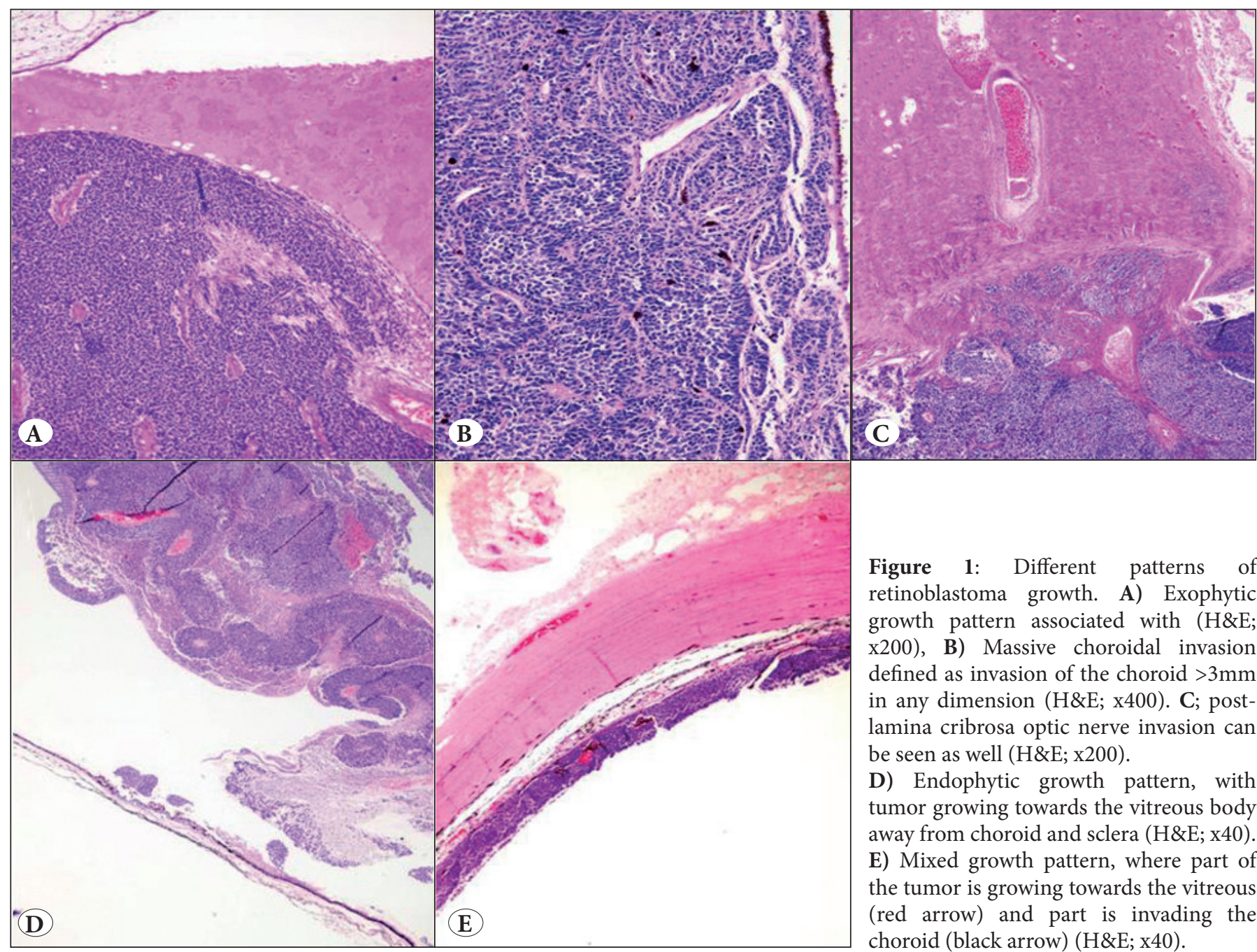

Figure 1: Different patterns of retinoblastoma growth. A) Exophytic growth pattern associated with (H\&E; $\mathrm{x} 200$ ), B) Massive choroidal invasion defined as invasion of the choroid $>3 \mathrm{~mm}$ in any dimension (H\&E; $\mathrm{x} 400)$. C; postlamina cribrosa optic nerve invasion can be seen as well (H\&E; x200).

D) Endophytic growth pattern, with tumor growing towards the vitreous body away from choroid and sclera (H\&E; x40). E) Mixed growth pattern, where part of the tumor is growing towards the vitreous (red arrow) and part is invading the choroid (black arrow) (H\&E; x40).

epithelium and therefore usually present with retinal detachment. Our analysis of endophytic and exophytic growth patterns in eyes with pathological diagnosis of retinoblastoma that had no treatment before enucleation showed that an exophytic component of the tumor is associated with higher risk of choroidal invasion, while an endophytic tumor component is associated with higher risk of vitreous seeding. A mixed growth pattern of the tumor was associated with more advanced IIRC group, more risk of neovascular glaucoma, and more risk of massive choroidal invasion. Optic nerve invasion as well as patients' age at diagnosis, gender, and tumor laterality had no correlation with the tumor growth pattern.

Reese (5) stated that endophytic tumors are more common than exophytic tumors in 1976. In 1990 Palazzi et al. (4) analyzed 297 retinoblastomas and classified them into either endophytic or exophytic and showed that $61 \%$ were endophytic and 39\% were exophytic tumors. Similarly our series showed that endophytic tumors are more common than exophytic tumors; $45 \%$ of our cases were endophytic, $33 \%$ were exophytic, and $21 \%$ had a mixed growth pattern. No single case in our series had the diffuse infiltrating growth pattern type, which is the rarest of all patterns. Taktikos (17) reported a diffuse infiltrating type in $1 \%$ of the cases.

Exophytic tumors grow towards the choroid and are expected to have higher risk of choroidal invasion than the endophytic type since the latter grows towards the vitreous and away from the choroid. Palazzi et al. (4) supported this theory by finding that $71 \%$ of tumors with choroidal invasion had an exophytic growth pattern. In this series we supported this finding and were able to show that massive choroidal invasion, as defined recently, was more likely to occur in tumors with an exophytic growth pattern, while not a single case of endophytic tumor had massive choroidal invasion. On the other hand, optic nerve invasion did not 
Table II: The impact of tumor growth pattern on pathological features

\begin{tabular}{|c|c|c|c|c|c|c|}
\hline & & Number & Endophytic (\%) & Exophytic (\%) & Mixed (\%) & P-value \\
\hline Total & & 42 & $19(45)$ & $14(33)$ & $9(22)$ & \\
\hline \multirow[t]{2}{*}{ Sex } & Male & 19 & $11(58)$ & $5(26)$ & $3(16)$ & 0.296 \\
\hline & Female & 22 & $8(36)$ & $9(41)$ & $5(23)$ & \\
\hline \multirow[t]{2}{*}{ Laterality } & Unilateral & 24 & $11(46)$ & $10(42)$ & $3(12)$ & 0.4861 \\
\hline & Bilatertal & 17 & $8(47)$ & $4(24)$ & $5(29)$ & \\
\hline \multirow[t]{2}{*}{$\mathrm{NVG}^{*}$} & Yes & 11 & $3(27)$ & $3(27)$ & $5(46)$ & 0.0376 \\
\hline & No & 31 & $16(52)$ & $11(35)$ & $4(13)$ & \\
\hline \multirow[t]{2}{*}{ Choroid invasion } & Yes & 17 & $4(24)$ & $5(29)$ & $8(47)$ & 0.0286 \\
\hline & No & 25 & $15(60)$ & $9(36)$ & $1(4)$ & \\
\hline \multirow[t]{2}{*}{ if yes } & Focal & 11 & $4(36)$ & $4(36)$ & $3(28)$ & 0.0498 \\
\hline & Massive & 6 & $0(0)$ & $1(17)$ & $5(83)$ & \\
\hline \multirow[t]{2}{*}{$\mathrm{ON}^{* *}$ invasion } & Yes & 17 & $8(47)$ & $4(24)$ & $5(29)$ & 0.3211 \\
\hline & No & 25 & $11(44)$ & $10(40)$ & $4(16)$ & \\
\hline \multirow[t]{2}{*}{ if yes } & $\begin{array}{c}\text { Laminar or } \\
\text { Pre-Laminar }\end{array}$ & 12 & $6(50)$ & $4(33)$ & $2(17)$ & 0.2605 \\
\hline & Post-laminar & 5 & $2(40)$ & $0(0)$ & $3(60)$ & \\
\hline \multirow[t]{2}{*}{ Vitreous seeds } & Yes & 25 & $14(56)$ & $5(20)$ & $6(24)$ & 0.0448 \\
\hline & No & 17 & $5(29)$ & $9(53)$ & $3(18)$ & \\
\hline \multirow[t]{3}{*}{ IIRC $^{* * *}$} & $\mathrm{C}$ & 8 & $7(88)$ & $1(12)$ & $0(0)$ & 0.0407 \\
\hline & $\mathrm{D}$ & 20 & $7(35)$ & $10(50)$ & $3(15)$ & \\
\hline & $E$ & 14 & $5(36)$ & $3(21)$ & $6(43)$ & \\
\hline Metastasis & & 0 & 0 & 0 & 0 & \\
\hline Death & & 0 & 0 & 0 & 0 & \\
\hline
\end{tabular}

*NVG: Neovascular Glaucoma,

${ }^{* *}$ ON: Optic Nerve,

***IIRC: International Intraocular Retinoblastoma Classification (10).

correlate with tumor growth pattern in this series, similar to what was shown by Palazzi et al. (4) in their analysis of 297 cases. On the contrary, endophytic tumors were more likely to be associated with vitreous seeds than the exophytic type, probably due to the fact that direct contact of the tumor with the vitreous (no inner retinal border) makes it easier for few cells to escape the surface of the tumor and to invade the vitreous.

Wilson et al. (11) and Kaliki et al. (12) showed a higher incidence of high-risk features in Reese-Ellsworth (RE) (18) group $\mathrm{Vb}$ eyes (eyes with vitreous seeds) than group Va eyes (eyes without vitreous seeds); Wilson et al. (11) showed that group $\mathrm{Vb}$ eyes (eyes with vitreous seeds) were associated with a $58 \%$ risk of optic nerve invasion (laminar or post laminar), and only $29 \%$ risk of massive choroid invasion, and since our study showed that vitreous seeds were significantly more likely to be associated with an endophytic growth pattern (Table II), we can conclude that endophytic tumors are more likely to be associated with optic nerve invasion than choroid invasion.

A mixed tumor growth pattern was indicative of a more advanced tumor stage, and a long-standing damaging tumor. In this series, the mixed growth type was significantly associated with more advanced IIRC group, where $67 \%$ of the mixed tumors were IIRC group E, the most advanced stage of intraocular retinoblastoma. Similarly neovascular glaucoma was significantly seen more commonly with the mixed tumor type $(\mathrm{p}=0.0376)$. Palazzi et al. (4) showed a higher risk of glaucoma in exophytic type that might be due to ischemia secondary to long-standing retinal detachment, but in that series they divided the tumors into either endophytic or exophytic without evaluating the impact of the mixed growth pattern on their cases. 
Of interest, not a single case in our series had metastasis although one third was IIRC group E, and none of them had chemotherapy before enucleation. This is consistent with Zhao's et al. (19) findings who recently found that chemotherapy before enucleation in group $\mathrm{E}$ eyes can downstage pathologic evidence of extraocular extension, and therefore increase the risk of metastatic death from reduced surveillance and inappropriate management of high-risk disease, and similar to our results, none of their patients who had primary enucleation without chemotherapy had metastasis (19).

This study examined the impact of retinoblastoma growth pattern on clinical and pathological features. Although this is a unique work, it is retrospective and of a limited size. Therefore, a larger and more comprehensive multicenter study needs to be performed to better analyze the impact of tumor growth pattern on the clinical and pathological features of the tumor, which may add to our understanding this rare life-threatening disease.

\section{REFERENCES}

1. International Incidence of Childhood Cancer, Vol. II. IARC Sci Publ. 1998;144:1-391.

2. Kivela T. The epidemiological challenge of the most frequent eye cancer: Retinoblastoma, an issue of birth and death. Br J Ophthalmol. 2009;93:1129-31.

3. Jaradat I, Yousef YA, Mehyar M, Sultan I, Khurma S, AlRawashded K, Wilson M, Qaddoumi I, Salem A, Alnawaiseh I. Retinoblastoma in Jordan: An epidemiological study (20062010). Hematol Oncol Stem Cell Ther. 2011;4:126-31.

4. Palazzi M, Abramson DH, Ellsworth RM. Endophytic vs. exophytic unilateral retinoblastoma: Is there any real difference? J Pediatr Ophthalmol Strabismus. 1990;27:255-8.

5. Reese AB. Tumors of the eye. Vol:11. Hagerstown, NY: Harper \& Row;1976.

6. Bhatnagar R, Vine AK. Diffuse infiltrating retinoblastoma. Ophthalmology. 1991; 98:1657-61.

7. Walton DS, Mukai S, Grabowski EF, Munzenrider JE, Dryja TP. Case records of the Massachusetts General Hospital. Case 5-2006. An 11-year-old girl with loss of vision in the right eye. N Engl J Med. 2006;354:741-8.
8. Abramson DH. The diagnosis of retinoblastoma. Bull N Y Acad Med. 1988;64:283-317.

9. Howard GM, Ellsworth RM. Differential diagnosis of retinoblastoma. A statistical survey of 500 children. I. Relative frequency of the lesions which simulate retinoblastoma. Am J Ophthalmol. 1965; 60:610-8.

10. Linn Murphree A. Intraocular retinoblastoma: The case for a new group classification. Ophthalmol Clin North Am. 2005;18:viii, 41-53.

11. Wilson MW, Qaddoumi I, Billups C, Haik BG, RodriguezGalindo C. A clinicopathological correlation of 67 eyes primarily enucleated for advanced intraocular retinoblastoma. $\mathrm{Br} J$ Ophthalmol. 2011;95:553-8.

12. Kaliki S, Shields CL, Rojanaporn D, Al-Dahmash S, McLaughlin JP, Shields JA, Eagle RC Jr. High-risk retinoblastoma based on international classification of retinoblastoma: Analysis of 519 enucleated eyes. Ophthalmology. 2013;120:997-1003.

13. Khelfaoui F, Validire P, Auperin A, Quintana E, Michon J, Pacquement H, Desjardins L, Asselain B, Schlienger P, Vielh P. Histopathologic risk factors in retinoblastoma: A retrospective study of 172 patients treated in a single institution. Cancer. 1996; 77:1206-13.

14. Hungerford J. Factors influencing metastasis in retinoblastoma. Br J Ophthalmol. 1993;77:541.

15. Kopelman JE, McLean IW, Rosenberg SH. Multivariate analysis of risk factors for metastasis in retinoblastoma treated by enucleation. Ophthalmology. 1987;94:371-7.

16. Chantada GL, Casco F, Fandiño AC, Galli S, Manzitti J, Scopinaro M, Schvartzman E, de Dávila MT. Outcome of patients with retinoblastoma and postlaminar optic nerve invasion. Ophthalmology. 2007;114:2083-9.

17. Taktikos A. Investigation of retinoblastoma with special reference to histology and prognosis. Br J Ophthalmol. 1966;50:225-34.

18. Reese AB, Ellsworth RM. The evaluation and current concept of retinoblastoma therapy. Trans Am Acad Ophthalmol Otolaryngol. 1963;67:164-72.

19. Zhao J, Dimaras H, Massey C, Xu X, Huang D, Li B, Chan HS, Gallie BL. Pre-enucleation chemotherapy for eyes severely affected by retinoblastoma masks risk of tumor extension and increases death from metastasis. J Clin Oncol. 2011;29:845-51. 